\title{
Tanggap Pertumbuhan dan Perkembangan Jagung Ketan terhadap Pemberian Amelioran dan Pupuk NPK pada Tanah Ultisol
}

\section{The Response of Growth and Development of Glutinous Corn to Ameliorant Application and NPK Fertilizer on Ultisol Soil}

\author{
Dini Harini ${ }^{*}$, $\operatorname{Radian}^{2}$, dan Iwan Sasli \\ ${ }^{1}$ Program Studi Magister Agroteknologi, Fakultas Pertanian, UniversitasTanjungpura \\ ${ }^{2}$ Jurusan Budidaya Pertanian, Fakultas Pertanian, Universitas Tanjungpura \\ Jl. Prof. Dr. H. Hadari Nawawi Pontianak 78124, Indonesia
}

Diterima 23 Januari 2021/Disetujui 31 Maret 2021

\begin{abstract}
The application of various types of organic matter as ameliorant and NPK fertilizer can increase the fertility of ultisol soil, physically and chemically. The study aimed to determine the effect of ameliorant types, the dose of NPK fertilizer and their interaction on the growth and development of glutinous corn on ultisol soil. The research was conducted in Bengkayang Regency, West Kalimantan from March to August 2020. The research used a factorial randomized block design. The first factor was the types of ameliorants with 5 levels, namely corncob biochar, corn waste bokashi, rice straw bokashi, cow manure, and chicken manure. The second factor was the dosage of NPK fertilizer with 4 levels, i.e., 100, 200, 300, and 400 $\mathrm{kg} \mathrm{ha} \mathrm{H}^{-1}$. The chicken manure ameliorant increased plant height 2, 4, and 6 WAP (weeks after planting), ear diameter, ear length, ear weight per ear, and ear weight per plot. The best dose of NPK fertilizer for glutinous maize production is $200 \mathrm{~kg}$ $\mathrm{ha}^{-1}$ on ear length and weight per ear, and a dose of $100 \mathrm{~kg} \mathrm{ha}^{-1}$ can stimulate plant growth based on plant height of 4 WAP. The combination of chicken manure and NPK fertilizer of $400 \mathrm{~kg} \mathrm{ha}^{-1}$ produced the highest root dry weight, crown dry weight, and relative growth rate.
\end{abstract}

Keywords: crop production, inorganic fertilizers, organic matter, soil fertility

\section{ABSTRAK}

Pengaplikasian jenis bahan organik sebagai amelioran dan pemupukan NPK dapat menambah kesuburan tanah ultisol melalui sifat fisik dan kimia. Tujuan penelitian untuk mempelajari pengaruh jenis amelioran, dosis pupuk NPK serta interaksinya terhadap pertumbuhan dan perkembangan jagung ketan pada tanah ultisol. Pelaksanaan percobaan di Kabupaten Bengkayang, Kalimantan Barat, pada bulan Maret sampai Agustus 2020. Percobaan disusun menggunakan rancangan acak kelompok faktorial. Faktor pertama pemberian jenis amelioran dengan 5 tarafyaitu biocar bonggol jagung, bokasi berangkas jagung, bokasi jerami padi, pupuk kandang sapi, pupuk kandang ayam. Faktor kedua pemberian dosis pupuk NPK dengan 4 taraf yaitu 100, 200, 300, dan $400 \mathrm{~kg} \mathrm{ha}$. Jenis amelioran pupuk kandang ayam dapat menambah tinggi tanaman 2, 4, dan 6 MST, diameter tongkol, panjang tongkol, bobot per tongkol, dan bobot tongkol per petak. Dosis pupuk NPK yang tebaik untuk produksi jagung ketan yaitu $200 \mathrm{~kg} \mathrm{ha-1}$ pada panjang tongkol dan bobot per tongkol, dan dosis $100 \mathrm{~kg} \mathrm{ha}^{-1}$ dapat memacu pertumbuhan tanaman yaitu pada tinggi tanaman 4 MST. Kombinasi jenis amelioran dari pupuk kandang ayam dan pupuk NPK $400 \mathrm{~kg} \mathrm{ha}^{-1}$ menghasilkan bobot kering akar, bobot kering tajuk,dan laju pertumbuhan relatif yang tertinggi.

Kata kunci: bahan organik, kesuburan tanah, produksi tanaman, pupuk anorganik

\section{PENDAHULUAN}

Jagung ketan (Zea mays var. ceratina) termasuk salah satu jenis jagung yang berpotensi untuk dikembangkan oleh petani sebagai sumber diversifikasi pangan dan bahan industri karena kandungan protein serat lemak

\footnotetext{
* Penulis untuk korespondensi. e-mail: diniharini40@gmail.com
}

dan karbohidrat biji jagung ketan sangat memadai untuk dilakukan pengembangan sebagai bahan pangan (Suarni, 2013). Berdasarkan data kementerian Pertanian (2015), produktivitas jagung di Kalimantan Barat baru mencapai 3.26 ton $\mathrm{ha}^{-1}$, sedangkan produktivitas jagung nasional mencapai 5.3 ton ha $^{-1}$. Kondisi tersebut mendorong upaya intensifikasi lahan produksi jagung di Kalimantan Barat, khususnya di tanah Ultisol. 
Tanaman jagung banyak dikembangkan oleh masyarakat di Kabupaten Bengkayang pada jenis tanah ultisol. Sistem pertanian yang tidak berorientasi pada pola pertanian berkelanjutan selama ini menjadi dampak menurunnya produksi tanaman jagung khususnya di Kabupaten Bengkayang. Kurangnya penggunaan bahan organik dalam kegiatan budidaya tanaman menjadi penyebab menurunnya kualitas lahan budidaya yang digunakan sehingga pada akhirnya menurunkan produktivitas tanaman.

Bahan organik yang digunakan dalam penelitian ini yaitu biocar bonggol jagung, bokasi berangkas jagung, bokasi jerami padi, pupuk kandang sapi dan pupuk kandang ayam. Secara umum jenis amelioran yang diaplikasikan ke dalam agregat tanah akan memberikan pengaruh yang berbeda terhadap tingkat kesuburan tanah secara fisik, kimia dan biologi, tergantung pada bahan pembentuknya, dengan demikian dapat menghasilkan pertumbuhan dan perkembangan tanaman yang berbeda pula. Menurut ElHamid et al. (2013) pengaplikasian bahan organik sebagai amelioran ke dalam tanah dapat menambah kesuburan tanah yaitu melalui perbaikan sifat fisik, kimia dan biologi tanah yaitu menambah kemampuan tanah menahan air, dan meningkatkan ketersediaan unsur hara untuk tanaman (Bouajila dan Sanaa, 2011).

Pemberian pupuk NPK dibutuhkan dalam budidaya tanaman karena unsur hara yang terkandung dalam bahan organik tidak sepenuhnya dapat memenuhi kebutuhan tanaman serta kondisi hara di dalam tanah ultisol yang sangat rendah, namun dengan pemberian bahan organik diharapkan mampu menurunkan penggunaan pupuk NPK. Menurut Suwandi et al. (2015) pengaplikasian pupuk organik mampu menurunkan kebutuhan pupuk anorganik sebanyak 50\% namun tetap meningkatkan produksi tanaman. Menurut Fiolita et al. (2017) penggunaan pupuk NPK dapat membantu dalam menambah pertumbuhan tanaman dan mempercepat pertumbuhan tanaman. Tujuan percobaan ini yaitu mempelajari pengaruh jenis amelioran, dosis pupuk serta interaksinya terhadap pertumbuhan dan perkembangan jagung ketan pada media ultisol.

\section{BAHAN DAN METODE}

Percobaan dilakukan di Kabupaten Bengkayang, Kalimantan Barat, pada bulan Maret sampai Agustus 2020. Percobaan disusun dengan menggunakan rancangan acak kelompok faktorial. Faktor pertama pemberian 5 jenis amelioran yaitu biocar bonggol jagung, bokasi berangkas jagung, bokasi jerami padi, pupuk kandang sapi, dan pupuk kandang ayam. Faktor kedua pemberian pupuk NPK dengan 4 taraf dosis yaitu $100,200,300$, dan $400 \mathrm{~kg} \mathrm{ha}^{-1}$.

Persiapan lahan dimulai dengan membersihkan gulma secara manual menggunakan parang, selanjutnya pengolahan lahan dilakukan menggunakan hand traktor dan dibuat bedengan dengan ukuran $2.25 \mathrm{~m}$ x $2.75 \mathrm{~m}$. Amelioran diaplikasikan dengan cara diaduk rata menggunakan cangkul pada setiap bedeng dengan dosis yang disetarakan berdasarkan hasil penelitian terkait yaitu biocar bonggol jagung 10 ton $\mathrm{ha}^{-1}$ (Chairunnas et al., 2014), bokasi berangkas jagung dan bokasi jerami padi 10 ton ha ${ }^{-1}$ (Wirda et al. 2016), pupuk kandang sapi dan pupuk kandang ayam 15 ton ha $^{-1}$ (Yoseva et al., 2015), selain itu diaplikasikan kapur dolomit sebanyak 1.26 ton ha $^{-1}$, selanjutnya diinkubasi selama 7 hari.

Penanaman dilakukan dengan cara ditugal menggunakan jarak tanam $75 \mathrm{~cm}$ x $25 \mathrm{~cm}$. selanjutnya pemupukan diberikan sebanyak 3 kali yaitu pada umur tanaman 7, 15, dan 28 HST (hari setelah tanam), setiap periode aplikasi, dosis pupuk yang diberikan yaitu $\left(\mathrm{p}_{1}=\right.$ 2.63 g per tanaman, $p_{2}=5.27$ g per tanaman, $p_{3}=7.90$ g per tanaman, dan $\mathrm{p}_{4}=10.53 \mathrm{~g}$ per tanaman). Pemeliharaan yang dilakukan meliputi penyiangan gulma dan penyiraman. Hama yang menyerang tanaman selama penelitian yaitu hama belalang, ulat grayak, kutu daun, kumbang bubuk, penggerek batang serta penggerek tongkol, pengendalian dilakukan dengan cara menyemprot insektisida berbahan aktif $40 \mathrm{WP}$, selain itu hama yang ditemukan diambil secara manual untuk dikendalikan. Panen dilakukan terhadap tongkol yang telah memenuhi ciri-ciri panen yaitu warna kelobot sudah berwarna hijau kecoklatan, rambut tongkol berwarna coklat kehitaman dan kering, serta biji telah mengeras dan menunjukkan adanya blacklayer pada titik tumbuh.

Pengamatan pertumbuhan dan hasil tanaman meliputi tinggi tanaman 2, 4, dan 6 minggu setelah tanaman (MST) dengan mengukur panjang tanaman dari tanah sampai pada ujung daun bendera. Bobot kering tajuk dan bobot kering akar diamati pada fase vegetatif maksimum dengan suhu oven $70{ }^{\circ} \mathrm{C}$ selama $2 \times 24$ jam. Tongkol jagung dipisahkan dari kelobotnya terlebih dahulu kemudian dilakukan pengamatan yaitu panjang tongkol diukur dari pangkal hingga ujung tongkol menggunakan meteran, diameter tongkol diamati menggunakan jangka sorong pada pangkal, tengah dan ujung tongkol kemudian dirata-ratakan, bobot per tongkol diamati dengan cara menimbang setiap satuan sampel tongkol dan bobot tongkol per petak diamati dengan menimbang seluruh tongkol yang dipanen pada setiap petak, laju pertumbuhan relatif dengan mengamati bobot kering tanaman pada $8,13,18,23,28,33$, dan 38 HST diukur menggunakan rumus (Shon et al., 1997):

$$
\mathrm{LPR}=\frac{(\mathrm{W} 2-\mathrm{W} 1)}{(\mathrm{t} 2-\mathrm{t} 1} x \mathrm{G}
$$

Keterangan: $\mathrm{LPR}=$ laju pertumbuhan relatif, $\mathrm{W}_{1}$ dan $\mathrm{W}_{2}=$ berat kering tanaman pada umur pengamatan ke-1 dan ke-2, $\mathrm{t}_{1}$ dan $\mathrm{t}_{2}=$ umur tanaman pengamatan ke-1 dan-ke-2, $\mathrm{G}=$ luas jarak tanam.

Data hasil pengukuran selanjutnya ditabulasi dan dianalisis menggunakan analisis ragam, apabila hasil analisis ragam berpengaruh nyata maka dilakukan uji lanjut menggunakan BNJ 5\% karena percobaan yang dibandingkan $>3$ perlakuan sehingga dapat diketahui perbedaan pada setiap taraf perlakuan. 


\section{HASIL DAN PEMBAHASAN}

\section{Kandungan Unsur Hara dari Jenis Amelioran}

Kandungan unsur hara pada berbagai jenis amelioran yang digunakan sangat menentukan kualitas dari jenis amelioran tersebut. Berdasarkan hasil analisis Laboratorium terhadap berbagai jenis amelioran pada Tabel 1 menunjukkan bahwa kandungan unsur hara tertinggi yaitu pada pupuk kandang ayam dengan kandungan $\mathrm{N} \mathrm{2.46 \% ,} \mathrm{P} \mathrm{4.67 \% ,} \mathrm{K}$ $2.43 \%$, Ca $8.58 \%$ dan Mg 0.73\%. Hal ini disebabkan nilai rasio $\mathrm{C} / \mathrm{N}$ pada pupuk kandang ayam yang lebih rendah dari jenis amelioran lainnya yaitu 7.20, menandakan tingkat kematangan bahan oraganik yang lebih sempurna.

Menurut Surtinah (2013) semakin rendah nilai rasio $\mathrm{C} / \mathrm{N}$ maka mengindikasikan tingkat kematangan bahan organik semakin sempurna dengan demikian kandungan unsur hara akan semakin meningkat. Prastya et al. (2015) menyatakan bahwa bahan organik yang mempunyai rasio $\mathrm{C} / \mathrm{N}$ rendah cenderung dirombak lebih cepat dibandingkan dengan bahan organik yang memiliki rasio $\mathrm{C} / \mathrm{N}$ tinggi, sehingga akan menambah kesuburan tanah yang lebih baik. Sejalan dengan hasil penelitian Pangaribuan et al. (2012), bahwa pupuk kandang ayam memiliki kandungan unsur hara N, P dan K yang lebih banyak dari pada pupuk kandang jenis ternak lainnya karena kotoran padat pada ternak unggas tercampur dengan kotoran cairnya.

\section{Tinggi Tanaman}

Jenis amelioran yang diaplikasikan berpengaruh signifikan terhadap tinggi tanaman 2, 4, dan 6 MST. Tabel 2 menunjukkan bahwa rata-rata tinggi tanaman jagung pada pemberian pupuk kandang ayam yaitu secara berurutan yaitu $53.35 \mathrm{~cm}, 154.08 \mathrm{~cm}$, dan $204.19 \mathrm{~cm}$ berbeda nyata dengan tinggi tanaman pada perlakuan jenis amelioran lainnya. Pertumbuhan tanaman yang lebih baik dengan aplikasi pupuk kandang ayam sesuai dengan pernyataan Silalahi et al. (2018) bahwa pada jenis amelioran dari pupuk kandang ayam lebih baik dalam menambah kesuburan tanah melalui percepatan proses dekomposisi. Selain itu, kandungan nitrogen yang cukup tinggi dalam pupuk kandang ayam sangat berpengaruh dalam merangsang pembesaran dan pembelahan sel (Sinabariba et al., 2013).
Berdasarkan hasil uji regresi pada Gambar 1 menunjukkan bahwa peningkatan dosis pupuk NPK yang diaplikasikan terhadap tanaman jagung ketan pada tanah ultisol diikuti dengan penurunan tinggi tanaman 2, 4, dan 6 MST pada dosis 300 dan $400 \mathrm{~kg} \mathrm{ha}^{-1}$ dengan persamaan pada tinggi tanaman 2 MST $\overline{\mathrm{Y}}=-0.0042 \mathrm{x}+36.06\left(\mathrm{R}^{2}=\right.$ $0.2527)$, pada tinggi tanaman 4 MST $\bar{Y}=-0.0154 x+95.415$ $\left(\mathrm{R}^{2}=0.1985\right)$, dan pada tinggi tanaman $6 \mathrm{MST} \overline{\mathrm{Y}}=0.0033 \mathrm{x}$ $+156.14\left(\mathrm{R}^{2}=0.0082\right)$ dengan titik tertinggi pada NPK 200 $\mathrm{kg} \mathrm{ha}{ }^{-1}$, menghasilkan tinggi tanamanan secara berurutan yaitu rata-rata $35.98 \mathrm{~cm}, 97.31 \mathrm{~cm}$, dan 161,49 cm.

Menurut Nuryani et al. (2019) pengaplikasian pupuk yang sesuai dengan takaran dan kebutuhan pada tanaman dapat meningkatkan pertumbuhan dan hasil tanaman. Pemupukan yang berlebihan terhadap tanaman akan mengakibatkan larutan tanah menjadi lebih pekat dan menyebabkan proses osmosis menjadi terhambat, sehingga mempengaruhi proses fisiologis tanaman yang mengakibatkan pertumbuhan tanaman menjadi menurun (Kosasih dan Heryati, 2006).

\section{Bobot Kering Akar}

Tabel 3 menunjukkan bahwa rata-rata bobot kering akar jagung tertinggi diperoleh pada interaksi pupuk kandang ayam dan pupuk NPK $400 \mathrm{~kg} \mathrm{ha}^{-1}$ yaitu $3.66 \mathrm{~g}$ berbeda nyata dengan bobot kering akar pada perlakuan lainnya. Menurut Hanum (2013) pengaplikasian pupuk organik dapat meningkatkan bobot kering akar. Sejalan dengan pendapat Sertua et al. (2014) bahwa bahan organik yang diaplikasikan dapat menyebabkan tanah menjadi lebih remah sehingga akar akan mudah berkembang dan penyerapan unsur hara akan semakin optimal. Menurut Prasetyo et al. (2014) meningkatnya pori-pori tanah menyebabkan ketersediaan udara dan penetrasi akar semakin meningkat, mempengaruhi proses respirasi akar, penyerapan hara yang nantinya akan mempengaruhi perkembangan dan pertumbuhan perakaran tanaman.

\section{Bobot Kering Tajuk}

Hasil analisis ragam pada Tabel 4 menunjukkan bahwa terdapat interaksi yang nyata antara pupuk kandang ayam dan pupuk NPK dengan dosis $400 \mathrm{ha}^{-1}$ yaitu rata-

Tabel 1. Kandungan unsur hara dari jenis amelioran pupuk kandang ayam, pupuk kandang sapi, bokasi jerami padi, bokasi berangkas jagung, dan biocar bonggol jagung

\begin{tabular}{|c|c|c|c|c|c|c|c|c|}
\hline \multirow{2}{*}{ Jenis amelioran } & \multirow{2}{*}{$\mathrm{pH}$} & \multirow{2}{*}{$\begin{array}{c}\text { C- } \\
\text { Organik }\end{array}$} & \multirow{2}{*}{$\begin{array}{c}\text { N-total } \\
(\%)\end{array}$} & \multirow{2}{*}{$\mathrm{C} / \mathrm{N}$ rasio } & $\mathrm{P}$ & $\mathrm{K}$ & $\mathrm{Ca}$ & $\mathrm{Mg}$ \\
\hline & & & & & \multicolumn{4}{|c|}{$(\%)$} \\
\hline Pupuk kandang ayam & 7.36 & 17.72 & 2.46 & 7.20 & 4.67 & 2.43 & 8.59 & 0.73 \\
\hline Pupuk kandang sapi & 6.28 & 22.56 & 1.65 & 13.67 & 0.68 & 0.28 & 0.32 & 0.46 \\
\hline Bokasi jerami padi & 6.77 & 30.50 & 1.86 & 16.40 & 0.87 & 0.43 & 0.28 & 0.38 \\
\hline Bokasi berangkas jagung & 7.25 & 22.37 & 1.51 & 14.81 & 0.61 & 0.48 & 0.22 & 0.41 \\
\hline Biocar bonggol jagung & 10.61 & 40.28 & 1.17 & 34.43 & 0.65 & 2.82 & 0.22 & 0.19 \\
\hline
\end{tabular}

Keterangan: Hasil analisis Laboratorium Kimia dan Kesuburan Tanah, Fakultas Pertanian, Universitas Tanjungpura, 2020 
Tabel 2. Rata-rata tinggi tanaman, diameter tongkol jagung ketan (mm), panjang tongkol jagung ketan (cm) dan bobot tongkol jagung ketan (g) pada berbagai jenis amelioran dan dosis pupuk NPK

\begin{tabular}{|c|c|c|c|c|c|c|c|}
\hline \multirow{2}{*}{ Jenis amelioran } & \multicolumn{3}{|c|}{ Tinggi tanaman $(\mathrm{cm})$} & \multirow{2}{*}{$\begin{array}{c}\text { Diameter } \\
\text { tongkol } \\
(\mathrm{mm})\end{array}$} & \multirow{2}{*}{$\begin{array}{c}\text { Panjang } \\
\text { tongkol } \\
(\mathrm{cm})\end{array}$} & \multirow{2}{*}{$\begin{array}{l}\text { Bobot per } \\
\text { tongkol } \\
(\mathrm{g})\end{array}$} & \multirow{2}{*}{$\begin{array}{c}\text { Bobot } \\
\text { tongkol per } \\
\text { petak }(\mathrm{kg})\end{array}$} \\
\hline & $2 \mathrm{MST}$ & $4 \mathrm{MST}$ & $6 \mathrm{MST}$ & & & & \\
\hline Biocar bonggol jagung & $32.30 \mathrm{~b}$ & $75.27 \mathrm{c}$ & $144.98 b c$ & $41.71 \mathrm{bc}$ & $18.78 b$ & $161.54 \mathrm{~b}$ & $5.34 \mathrm{~b}$ \\
\hline Bokasi berangkas jagung & $29.07 \mathrm{bc}$ & $63.56 \mathrm{~d}$ & $132.65 \mathrm{c}$ & $40.52 \mathrm{c}$ & $18.49 b$ & $150.92 b$ & $4.68 b$ \\
\hline Bokasi jerami padi & $28.02 \mathrm{c}$ & $74.11 \mathrm{~cd}$ & $145.97 \mathrm{bc}$ & $41.54 \mathrm{bc}$ & $18.42 b$ & $158.41 b$ & $4.91 b$ \\
\hline Pupuk kandang sapi & $32.27 \mathrm{~b}$ & $90.85 b$ & $157.00 \mathrm{~b}$ & $42.55 \mathrm{ab}$ & $18.23 b$ & $163.48 b$ & $5.07 \mathrm{~b}$ \\
\hline Pupuk kandang ayam & $53.35 \mathrm{a}$ & $154.08 \mathrm{a}$ & $204.19 a$ & $43.53 \mathrm{a}$ & $19.87 \mathrm{a}$ & $221.48 \mathrm{a}$ & $6.87 \mathrm{a}$ \\
\hline BNJ 5\% & 3.44 & 11.42 & 15.27 & 1.65 & 0.98 & 20.72 & 0.69 \\
\hline \multirow{2}{*}{$\begin{array}{l}\text { Dosis pupuk NPK } \\
\left(\mathrm{kg} \mathrm{ha}^{-1}\right)\end{array}$} & \multicolumn{3}{|c|}{ Tinggi tanaman $(\mathrm{cm})$} & Diameter & Panjang & Bobot per & Bobot \\
\hline & $2 \mathrm{MST}$ & $4 \mathrm{MST}$ & $6 \mathrm{MST}$ & $\begin{array}{c}\text { tongkol } \\
\text { (mm) }\end{array}$ & $\begin{array}{c}\text { tongkol } \\
(\mathrm{cm})\end{array}$ & $\begin{array}{l}\text { tongkol } \\
(\mathrm{g})\end{array}$ & $\begin{array}{c}\text { tongkol per } \\
\text { petak }(\mathrm{kg})\end{array}$ \\
\hline 100 & 34.84 & $90.10 \mathrm{ab}$ & 152.22 & 41.54 & $18.01 \mathrm{~b}$ & $157.12 b$ & 5.07 \\
\hline 200 & 35.98 & $97.31 \mathrm{a}$ & 161.49 & 41.99 & $18.98 \mathrm{a}$ & $175.46 \mathrm{a}$ & 5.51 \\
\hline 300 & 35.65 & $92.21 \mathrm{ab}$ & 160.47 & 42.23 & $18.98 \mathrm{a}$ & $178.39 \mathrm{a}$ & 5.53 \\
\hline 400 & 33.54 & $86.68 b$ & 153.66 & 42.12 & $19.05 \mathrm{a}$ & $173.69 \mathrm{ab}$ & 5.38 \\
\hline BNJ 5\% & - & 9.58 & - & - & 0.82 & 17.39 & - \\
\hline
\end{tabular}

Keterangan: Angka yang diikuti huruf yang sama pada kolom yang sama tidak berbeda nyata berdasarkan uji BNJ taraf 5\%

rata 16.12 g yang berbeda nyata dengan bobot kering tajuk pada perlakuan lainnya. Meningkatnya bobot kering tajuk yang diperoleh dalam penelitian ini diakibatkan oleh semakin meningkatnya pertumbuhan akar tanaman yang menyebabkan pertumbuhan tanaman secara keseluruhan akan semakin meningkat secara cepat (Sandrawati et al., 2016).

Menurut Agusni dan Satriawan (2014) fungsi akar tanaman yaitu untuk menyerap unsur nutrisi di dalam tanah dan ditranslokasikan keseluruh jaringan tanaman, sehingga pembentukan klorofil daun akan berjalan secara optimal yang digunakan untuk proses fotosintesis. Meningkatnya fotosintesis yang terjadi akan meningkatkan terbentuknya fotosintat yang dihasilkan tanaman yaitu berupa senyawa-

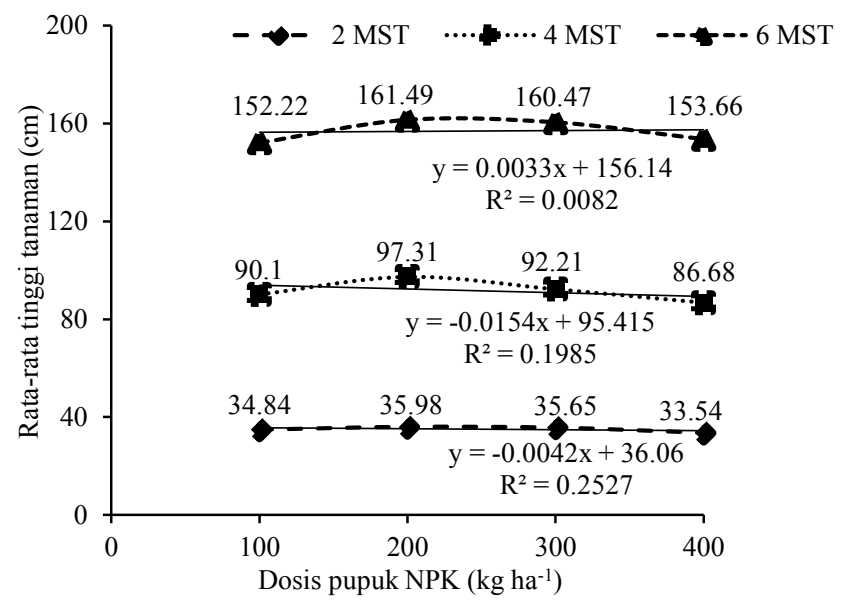

Gambar 1. Uji regresi pemberian berbagai dosis NPK terhadap tinggi tanaman jagung ketan yang diuji 2, 4, dan 6 MST senyawa organik yang akan disebarkan pada seluruh jaringan tanaman dan sehingga dapat menambah biomassa tanaman.

\section{Laju Pertumbuhan Relatif}

Berdasarkan hasil penelitian pada Gambar 2 menunjukkan bahwa laju pertumbuhan relatif pada awal pengamatan yaitu umur tanaman 8-13 HST hingga umur pengamatan 23-28 HST mengalami peningkatan secara signifikan dan puncak pertumbuhan tanaman tertinggi yaitu pada 23-28 HST dengan hasil yang lebih baik pada pemberian pupuk kandang ayam yang dikombinasi dengan berbagai dosis pupuk NPK, selanjutnya pada umur pengamatan 28-33 HST dan 33-38 HST pertumbuhan tanaman mengalami penurunan, hal ini diakibatkan karena tanaman secara bertahap memasuki fase generatif, sehingga efisiensi fotosintat yang dihasilkan tidak lagi digunakan tanaman untuk proses pertumbuhan tetapi lebih difokuskan untuk pembentukan bunga dan buah.

Laju pertumbuhan relatif jagung yang digambarkan dengan biomassa tanaman disebabkan oleh proses penyerapan nutrisi dan air yang lebih tinggi, sehingga memacu perkembangan jaringan pada tanaman seperti akar, batang, dan daun yang mengakibatkan aktifitas fotosintesis dan akan meningkat biomassa tanaman. Menurut Safuan dan Bahrun (2012) untuk proses pertumbuhan vegetatif, tanaman sangat membutuhkan unsur hara $\mathrm{N}, \mathrm{P}$, dan $\mathrm{K}$, dalam jumlah yang cukup sehingga dengan terpenuhinya unsur hara tersebut tanaman akan memaksimalkan proses metabolisme yang pada akhirnya akan berdampak terhadap pembesaran dan pembelahan sel. 
Tabel 3. Rata-rata bobot kering akar jagung ketan (g) pada kombinasi jenis amelioran dan dosis pupuk NPK

\begin{tabular}{llllll}
\hline \multirow{2}{*}{ Jenis amelioran } & \multicolumn{3}{c}{ Dosis pupuk NPK (g per tanaman) } & Rata-rata \\
\cline { 2 - 5 } & 100 & 200 & 300 & 400 & 1.79 \\
Biocar bonggol jagung & $1.68 \mathrm{jk}$ & $1.85 \mathrm{hi}$ & $1.82 \mathrm{hi}$ & $1.82 \mathrm{hi}$ & 1.75 \\
Bokasi berangkas jagung & $1.63 \mathrm{k}$ & $1.63 \mathrm{k}$ & $1.89 \mathrm{gh}$ & $1.84 \mathrm{hi}$ & 1.85 \\
Bokasi jerami padi & $1.76 \mathrm{ij}$ & $1.82 \mathrm{hi}$ & $1.83 \mathrm{hi}$ & $1.97 \mathrm{~g}$ & 2.23 \\
Pupuk kandang sapi & $2.09 \mathrm{f}$ & $2.40 \mathrm{~d}$ & $2.23 \mathrm{e}$ & $2.21 \mathrm{e}$ & 3.34 \\
Pupuk kandang ayam & $3.23 \mathrm{bc}$ & $3.12 \mathrm{c}$ & $3.33 \mathrm{~b}$ & $3.66 \mathrm{a}$ & 2.30 \\
\hline Rata-rata & 2.08 & 2.16 & 2.22 & & \\
\hline BNJ 5\% & 0.11 & & & \\
\hline
\end{tabular}

Keterangan: Angka yang diikuti huruf yang sama tidak berbeda nyata berdasarkan uji BNJ taraf 5\%

\section{Panjang Tongkol}

Hasil analisis ragam menunjukkan bahwa pemberian berbagai jenis amelioran dan dosis pupuk NPK secara mandiri berpengaruh nyata terhadap panjang tongkol. Tabel 2 menunjukkan bahwa panjang tongkol dengan pemberian pupuk kandang ayam diperoleh hasil yang lebih baik dan berbeda nyata panjang tongkol pada jenis amelioran lainnya, sedangkan panjang tongkol pada pemberian pupuk NPK sebanyak 200, 300, dan $400 \mathrm{~kg} \mathrm{ha}^{-1}$ diperoleh hasil yang sama baiknya dan berbeda nyata pada $100 \mathrm{~kg}$ $\mathrm{ha}^{-1}$. Bertambahnya panjang tongkol disebabkan oleh terpenuhinya kebutuhan nutrisi bagi tanaman, cahaya dan air dalam jumlah yang cukup sehingga menyebabkan hasil fotosintesis akan terbentuk secara optimal, fotosintat yang terbentuk akan disebarkan dan disimpan untuk pembentukan biji dan pemanjangan tongkol. Menurut Bastiana et al. (2013) bahwa tersedianya unsur hara dalam jumlah yang cukup dapat menambah aktivitas metabolisme tanaman sehingga lebih aktif dalam mendukung dalam proses pemanjangan dan pembesaran buah.

\section{Diameter Tongkol}

Diameter tongkol yang diperoleh berdasarkan hasil analisis ragam menunjukkan bahwa jenis amelioran yang diaplikasikan memberikan pengaruh yang signifikan, pada pengaplikasian pupuk NPK dan interaksi keduanya berpengaruh tidak nyata. Diameter tongkol pada pemberian pupuk kandang ayam berbeda tidak nyata dengan pengaplikasian pupuk kandang sapi, dan berbeda nyata dengan pemberian jenis amelioran lainnya (Tabel 2). Hal ini dipengaruhi oleh kemampuan pupuk kandang dalam menahan unsur hara dan melepaskan unsur hara sesuai yang diinginkan tanaman, sehingga dengan demikian diperoleh efektifitas dan efisiensi pemupukan menjadi lebih tinggi.

Menurut Ayunda (2014) ketersediaan fosfor untuk tanaman dapat membantu proses pembentukan dan pembesaran buah, fosfor sebagai bahan pembentuk ATP akan menjamin kesiapan energi bagi pertumbuhan sehingga penyusunan asimilat dan proses pengangkutannya pada jaringan penyimpanan dapat berjalan secara optimal. Hal ini mengakibatkan tongkol yang dihasilkan memiliki diameter yang besar.

\section{Bobot per Tongkol}

Pemberian jenis amelioran dan dosis pupuk NPK secara mandiri berpengaruh signifikan terhadap bobot per tongkol. Jenis amelioran dari pupuk kandang ayam merupakan perlakuan dengan bobot tongkol yang lebih baik dengan rata-rata $221.48 \mathrm{~g}$ dan berbeda nyata dengan bobot tongkol

Tabel 4. Rata-rata bobot kering tajuk jagung ketan (g) pada kombinasi jenis amelioran dan dosis pupuk NPK

\begin{tabular}{lccccc}
\hline \multirow{2}{*}{ Jenis amelioran } & \multicolumn{3}{c}{ Dosis Pupuk NPK (g per tanaman) } & Rata-rata \\
\cline { 2 - 5 } & 100 & 200 & 300 & 400 & 10.04 \\
Biocar bonggol jagung & $9.42 \mathrm{jk}$ & $10.35 \mathrm{hi}$ & $10.17 \mathrm{hi}$ & $10.22 \mathrm{hi}$ & 9.79 \\
Bokasi berangkas jagung & $9.14 \mathrm{k}$ & $9.12 \mathrm{k}$ & $10.60 \mathrm{gh}$ & $10.30 \mathrm{hi}$ & 10.33 \\
Bokasi jerami padi & $9.83 \mathrm{ij}$ & $10.19 \mathrm{hi}$ & $10.26 \mathrm{hi}$ & $11.03 \mathrm{~g}$ & 12.51 \\
Pupuk kandang sapi & $11.72 \mathrm{f}$ & $13.45 \mathrm{~d}$ & $12.51 \mathrm{e}$ & $12.35 \mathrm{e}$ & 14.67 \\
Pupuk kandang ayam & $14.20 \mathrm{bc}$ & $13.72 \mathrm{~cd}$ & $14.65 \mathrm{~b}$ & $16.12 \mathrm{a}$ & 12.00 \\
\hline Rata-rata & 10.86 & 11.37 & 11.64 & & \\
\hline BNJ 5\% & 0.58 & & & \\
\hline
\end{tabular}

Keterangan: Angka yang diikuti huruf yang sama tidak berbeda nyata berdasarkan uji BNJ taraf 5\% 

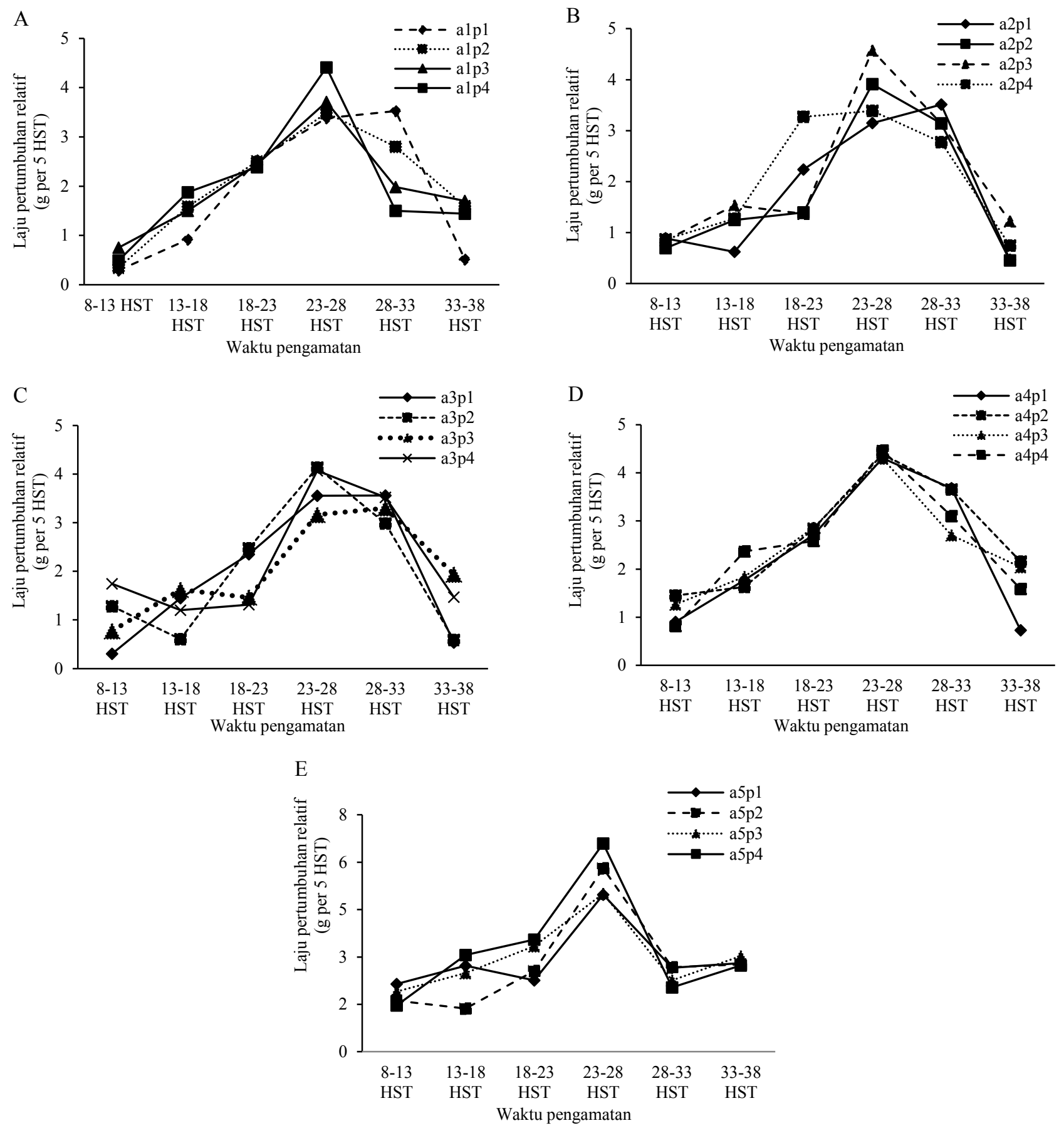

Gambar 2. Rerata laju pertumbuhan relatif (g) pada berbagai waktu pengamatan dengan pengaplikasian biocar bonggol jagung dan berbagai dosis NPK (A), bokasi berangkas jagung dan berbagai dosis NPK (B), bokasi jerami padi dan berbagai dosis NPK (C), pupuk kandang sapi dan berbagai dosis NPK (D), pupuk kandang ayam dan berbagai dosis NPK (E). al = biocar berangkas jagung 10 ton ha-1, a2 = bokasi berangkas jagung 10 ton ha ${ }^{-1}$, a3 = bokasi jerami padi 10 ton ha ${ }^{-1}$, a4 = pupuk kandang sapi 15 ton ha ${ }^{-1}$, a5 = pupuk kandang ayam 15 ton ha ${ }^{-1}$. p1 = pupuk NPK $100 \mathrm{~kg} \mathrm{ha}^{-1}, \mathrm{p} 2=$ pupuk NPK $200 \mathrm{~kg} \mathrm{ha}^{-1}$, p3 = pupuk NPK $300 \mathrm{~kg}$ ha-1, dan $\mathrm{p} 4=$ pupuk NPK $400 \mathrm{~kg} \mathrm{ha}^{-1}$

pada pemberian jenis amelioran lainnya. Bobot per tongkol pada pemberian pupuk NPK dengan dosis $300 \mathrm{~kg} \mathrm{ha}^{-1}$ ratarata $178.39 \mathrm{~g}$ berbeda tidak nyata dengan bobot tongkol pada pemberian dosis pupuk NPK sebanyak $200 \mathrm{~kg} \mathrm{ha}^{-1}$ dan $400 \mathrm{~kg} \mathrm{ha}^{-1}$, namun berbeda nyata dengan bobot tongkol pada pemberian pupuk NPK $100 \mathrm{~kg} \mathrm{ha}^{-1}$ (Tabel 2). Hal ini dipengaruhi oleh ketersediaan unsur hara fosfor dan kalium bagi tanaman yang lebih tinggi. Menurut Yetti et al. (2012) fosfor dapat membantu dalam menambah perkembangan ukuran tongkol dan biji, unsur hara kalium berperan dalam memacu proses pemindahan unsur hara dalam menambah kualitas tongkol. Hasil analisis Laboratorium Kimia dan Kesuburan Tanah pada Tabel 1 menunjukkan bahwa pupuk kandang ayam memiliki kandungan fosfor sebesar 4.67\% dan Kalium 2.43\% dibandingkan dengan jenis amelioran lainnya kandungan $\mathrm{P}$ dan $\mathrm{K}$ pada pupuk kandang ayam jauh 
lebih tinggi. Berdasarkan hasil penelitian Santosa et al. (2016) bahwa meningkatnya serapan P total oleh tanaman mampu meningkatkan bobot tongkol tanaman jagung.

\section{Bobot Tongkol per Petak}

Bobot tongkol per petak yang dihasilkan pada pemberian jenis amelioran secara mandiri menunjukkan pengaruh yang signifikan, namun pada pemberian berbagai dosis pupuk NPK serta interaksi keduanya diperoleh hasil yang sama baiknya. Rata-rata bobot tongkol per petak pada pemberian pupuk kandang ayam yaitu $1.87 \mathrm{~kg}$ berbeda nyata dengan bobot tongkol per petak pada pemberian jenis amelioran lainnya (Tabel 2). Indikator hubungan antara panjang tongkol, diameter tongkol, bobot per tongkol dengan bobot tongkol per petak secara umum menunjukkan bahwa terjadi suatu korelasi atau hubungan yang saling mempengaruhi yaitu dengan nilai koefisien korelasi $\left(\mathrm{r}^{2}\right)$ masing-masing secara berurutan yaitu 0.81, 0.78, 0.97.

Hubungan yang paling besar dalam meningkatkan bobot tongkol per petak yaitu bobot per tongkol dengan nilai $\mathrm{r}^{2} 97 \%$, yang artinya hanya terdapat 3\% faktor luar yang mempengaruhi bobot tongkol per petak. Hubungan panjang tongkol dalam meningkatkan bobot per petak yaitu sebesar $81 \%$, serta pada diameter tongkol dalam meningkatkan berat per petak yaitu sebesar $78 \%$. Sejalan dengan hasil penelitian Amare et al.(2015) bahwa penambahan jumlah biji per baris, diameter tongkol dan panjang tongkol berkorelasi positif dengan penambahan bobot tongkol, karena sebagian besar sifat secara genotip berhubungan erat dengan hasil tanaman.

\section{KESIMPULAN}

Jenis amelioran pupuk kandang ayam dapat memberikan pertumbuhan dan hasil yang terbaik pada karakter tinggi tanaman 2, 4, dan 6 MST, diameter tongkol, panjang tongkol, bobot per tongkol dan bobot tongkol per petak. Dosis pupuk NPK yang diperlukan untuk menghasilkan produksi yang terbaik yaitu sebanyak $200 \mathrm{~kg}$ $\mathrm{ha}^{-1}$ pada panjang tongkol dan bobot per tongkol, sedangkan pada dosis $100 \mathrm{~kg} \mathrm{ha}^{-1}$ merupakan dosis yang dapat memacu pertumbuhan tanaman yaitu pada tinggi tanaman 4 MST. Interaksi amelioran dan pupuk NPK yaitu pupuk kandang ayam dan NPK $400 \mathrm{~kg} \mathrm{ha}^{-1}$ pada karakter bobot kering akar, bobot kering tajuk, dan laju pertumbuhan relatif.

\section{DAFTAR PUSTAKA}

Agusni, M., H. Satriawan. 2014. Pengaruh olah tanah dan pemberian pupuk kandang terhadap sifat fisik tanah dan produksi tanaman jagung. J. Lentera 14:1-6.

Amare, K., H. Zeleke, G. Bultosa. 2015. Variabilty for yield, yield related traits and association among traits of sorgum (Sorghum bicolor L. Moench) varieties in wollo. J. Plant Breed. Crop Sci. 7:125-133.
Ayunda, N. 2014. Pertumbuhan dan hasil tanaman jagung manis (Zea mays saccharata Sturt.) pada beberapa konsentrasi sea minerals. Fakultas Pertanian Universitas Tamansiswa. Padang.

Bastiana, A., U. Trisnaningsih, S. Wahyuni. 2013. Pengaruh konsentrasi pupuk organik cair terhadap pertumbuhan dan hasil tanaman jagung manis (Zea mays var. saccharata Sturt.) Kurtival Bonanza F1. J. Agrijati. 22:1-20.

Bouajila, K., M. Sanaa. 2011. Effects of organic amendments on soil physicochemical and biological properties. J. Mater. Environ. Sci. 2:485- 490.

Chairunnas, A. Azis, B.A. Bakar, D. Darmadi. 2014. Pemanfaatan biocar dan efisiensi pemupukan jagung mendukung program pengelolaan tanaman terpadu di Provinsi Aceh. Prosiding seminar nasional agroinovasi spesifik lokasi untuk ketahanan pangan pada era masyarakat ekonomi ASEAN. Balai Pengkajian Teknologi Pertanian. Aceh 16 Januari 2021.

El-Hamid, A., R. Azza, F.A.A. Al-Kamar, M.E. Husein. 2013. Impact of some organic and biofertilizers soil amendments on the fertility status, some soil properties, and productivity of sandy soils. J. Soil Sci. and Agric. Eng. 4:989-1007.

Fiolita, V., A. Muin, Fahrizal. 2017. Penggunaan pupuk NPK mutiara untuk peningkatan pertumbuhan tanaman Gaharu aquilaria spp. pada lahan terbuka di tanah ultisol. J. Hutan Lestari 5:850-857.

Hanum, C. 2013. Pertumbuhan, hasil, dan mutu biji kedelai dengan pemberian pupuk organik dan fosfor. J. Agron. Indonesia 41:209-214.

Kementerian Pertanian. 2015. Modul pemberdayaan dalam upaya khusus peningkatan produksi padi, jagung dan kedelai tahun 2015. Kerjasama Kementerian Pertanian RI dengan Perguruan Tinggi. Jakarta, ID.

Kosasih, A.S., dan Y. Heryati. 2006. Pengaruh medium sapih terhadap pertumbuhan bibit Shorea selanica BI di persemaian. J. Penelit. Hutan dan Konservasi Alam. 3:147-155.

Nuryani, E., G. Haryono, Historiawati. 2019. Pengaruh dosis dan saat pemberian pupuk $\mathrm{P}$ terhadap hasil tanaman buncis (Phaseolus vulgaris L.) tipe tegak. J. Ilm Pertan. Trop. Subtrop. 4:14-17.

Pangaribuan, D.H., M. Yasir, N.K. Utami. 2012. Dampak bokashi kotoran ternak dalam pengurangan pemakaian pupuk anorganik pada budidaya tanaman tomat. J. Agron. Indonesia 40:204-210. 
Prasetyo, Y., H. Djatmiko, N. Sulistyaningsih. 2014. Pengaruh kombinasi bahan baku dan dosis biocar terhadap perubahan sifat fisika tanah pasiran pada tanaman jagung (Zea mays L.). J. Berk. Ilm. Pertan. $1: 1-5$.

Prastya, D., I. Wahyudi, Baharudin. 2015. Pengaruh jenis dan komposisi pupuk kandang ayam dan pupuk NPK terhadap serapan nitrogen dan hasil bawang merah (Allium ascalonicum L.) varietas lembah palu di entisol sidera. J. Agrotekbis. 3:707-706.

Safuan, L., A. Bahrun. 2012. Pengaruh bahan organik dan pupuk kalium terhadap pertumbuhan dan produksi tanaman melon (Cucumis melo L.) J. Agroteknos. 2:69-76.

Sandrawati, A., A. Setiawan, G. Kesumah. 2016. Pengaruh kelas kemiringan lereng dan penggunaan lahan terhadap sifat fisik tanah di Kawasan Penyangga Waduk Cirata Kecamatan Cipeundeuy Kabupaten Bandung Barat. J. Soilrens. 14:6-10.

Santosa, C.A., E. Anom, Murniati. 2016. Efektifitas pemberian pupuk hayati mikoriza terrhadap serapan $\mathrm{P}$, pertumbuhan serta produksi jagung manis (Zea mays saccaharata sturt.) di lahan gambut. J. Online Mhs. Fak. Pertan. Univ. Riau 3:1-9.

Sertua, H., J.A. Lubis, P. Marbun. 2014. Aplikasi kompos ganggang cokelat (Sargassum polycystum) diperkaya pupuk N, P, K terhadap inseptisol dan jagung. J. Agroekoteknologi 2:1538-1544.

Shon, T.K., T.A.D. Haryanto, T. Yoshida. 1997. Dry matter production and utilization of solar energy in one year old Bupleurum falcatum. J. Fac. Agr. Kyushu Univ. 41:133-139.
Silalahi, M.J., A.R. Malcky, M. Telleng, W.B. Kaunang. 2018. Pengaruh pemberian pupuk kandang ayam terhadap pertumbuhan tanaman sorgum sebagai pakan. J. Zootec. 38:286-295.

Sinabariba, A., B. Sinagian, S. Silitonga. 2013. Respon pertumbuhan bibit kakao (Theobroma cacao. L) terhadap pemberian kompos blotong dan pupuk N, P, $\mathrm{K}, \mathrm{Mg}$ pada media subsoil ultisol. J. Agroekoteknologi $1: 360-370$.

Suarni. 2013. Pengembangan pangan tradisional berbasis jagung mendukung diversifikasi pangan. J. Iptek Tanam. Pangan 8:39-47.

Suwandi, G.A. Sopha, M.P. Yufdy. 2015. Efektivitas pengelolaan pupuk organik, NPK, dan pupuk hayati terhadap pertumbuhan dan hasil bawang merah. J. Hort. 25:208-221.

Surtinah, S. 2013. Pengujian kandungan unsur hara dalam kompos yang berasal dari serasah tanaman jagung manis (Zea mays saccharata). J. Ilm. Pertan. 11:1117.

Wirda, W., P.D. Bandem, D. Zulfita. 2016. Pengaruh bokasi jerami padi terhadap pertumbuhan dan hasil tanaman jagung manis di lahan aluvial. J. Sains Mhs. Fak. Pertan. Univ. Tanjungpura 2:1-8.

Yetti, H., Nelvia, A. Pratama. 2012. Pengaruh pemberian berbagai macam kompos pada lahan ultisol terhadap pertumbuhan dan produksi jagung manis (Zea mays Saccharata Sturt). J. Agroetk. Trop. 1:31-37.

Yoseva, S., R.A.S. Maulana, H. Yetti. 2015. Pengaruh pemberian pupuk bokasi dan NPK terhadap pertumbuhan dan produksi tanaman jagung manis (Zea mays var saccharata Sturt). J. Online Mhs. Fak. Pertan. Univ. Riau $2: 1-7$. 